\title{
Critical Review of the Practice of Courts of Bosnia and Herzegovina in Resolving CHF Loan Disputes
}

\author{
Adriana Pranjic ${ }^{1}$, Stjepo Pranjic $^{2,3}$ \\ ${ }^{1}$ Faculty of Law, University in Mostar, Mostar, Bosnia and Herzegovina \\ ${ }^{2}$ Faculty of Law, University Vitez, Travnik, Bosnia and Herzegovina \\ ${ }^{3}$ Competion Council of BiH, Sarajevo, Bosnia and Herzegovina
}

Email address:

adriana.pranjic1@gmail.com (A. Pranjic), stjepo.pranjic@tel.net.ba(S. Pranjic), stjepo.pranjic@bihkonk.gov.ba (S. Pranjic)

\section{To cite this article:}

Adriana Pranjic, Stjepo Pranjic. Critical Review of the Practice of Courts of Bosnia and Herzegovina in Resolving CHF Loan Disputes. International Journal of Law and Society. Vol. 3, No. 3, 2020, pp. 140-153. doi: 10.11648/j.ijls.20200303.18

Received: August 18, 2020; Accepted: September 7, 2020; Published: September 19, 2020

\begin{abstract}
The practice of $\mathrm{BiH}$ courts in resolving CHF loan agreement disputes is poor. By Decision, No. AP-962/20 and Decision, No. AP-3877/17 of the Constitutional Court of BiH, they were rejected as inadmissible appeals, as they were allegedly prima facio unfounded. Appeals were filed against the judgments of the FBiH Supreme Court. All judgments of the Supreme and lower courts in $\mathrm{BiH}$ are challenged because they were made in a decisive reference to the decision of the Supreme Court of the FBiH, No. 580 P $13502316 \mathrm{Spp}$, dated 25.05.2016, which is a circumvention of rights and justice. In fact, in terms of Article 61 of the Law on Civil Procedure, "Official Gazette of the F BiH" no.: 53/03, 73/05, 19/06 and 98/15 (LCP), the Supreme Court, in that decision, expressed its understanding on legal issues from the subject of the loan agreement with a currency clause in CHF. It is obvious that these are not legal, but factual issues. If these were legal issues, then the courts would simply cite explicit answers to those questions as solutions to the law rather than constructing them linguistically. The first-instance court could not in any way refer to the legal understanding of the Supreme Court according to which the interest margin is sufficiently determinable without determining whether the contract contains information on the interest margin in the sense of Article 26, Article 50, Article 1065 and Article 1066 of the Law on Obligations, "Official Gazette of the SFRY," no. 29/78, 39/85, 45/89, 57/89, "Official Gazette of R BiH," no. 2/92, 13/93, 13/94, "Official Gazette of the F BiH," no. 29/03, 42/11. (LO). The courts could not reject the plaintiffs' claims for the return of unjustifiably higher interest collected, when this was proved by the Finding and the expert opinion.
\end{abstract}

Keywords: Judicial Practice, A Currency Board, Foreign Currency Loan, Currency Clause Indexed to the CHF, Libor, Variable Interest Rate

\section{Introduction}

During the financial crisis of 2008 , there was a violation of the imperative provisions of Bosnia and Herzegovina, the principles of civil and/or mandatory law and consumer rights by banks. Banks illegally approved Foreign Currency Loans (FCL) in Swiss francs (CHF), unjustifiably/illegally contracted currency clauses in $\mathrm{CHF}$ and prevented and violated the agreed variable interest rate regime.

The a priori ex legibus obligation of the banks was, in a simple and comprehensible way, not only to acquaint the loan users (LU) with the disputed contracting but also to establish that they also fully and clearly understood the same.
LU should have received the general terms of the contract, on one page because they are an integral part of the contract, which also means a recapitulation of the risk of contracting a currency clause in CHF. Contracts are challenged by the LUs, primarily due to violations of the provisions of mandatory regulations, i.e. given that contracts have the nature of consumer contracts ${ }^{1}$, the imbalance of rights and obligations of the contracting parties determines the unfairness/nullity of the contract.

"In the procedures of resolving disputes over loan

1 Contract on special-purpose loan credit lot no.: 1637297196 concluded on 28.04.08. between Hypo Alpe Adria Bank d.d. Mostar, kr. Branimira br. 2b as bank on the one hand and natural persons as $\mathrm{LU}$ on the other. 
agreements in CHF, concluded between the plaintiff as a LU, on the one hand and the defendant (Hypo Alpe Adria Bank dd) as the lender (predecessor of the defendant), on the other hand, the practice of courts in $\mathrm{BiH}$ is bad because there have not been any final verdicts for ten years, ${ }^{2}$ i.e. the verdicts of the courts in $\mathrm{BiH}$, are, as a rule, contrary to the verdicts of the Court of Justice of the EU and the courts of the EU member states. European court rulings have established a European standard according to which contracts of a currency clause in $\mathrm{CHF}$ and clauses on variable interest rates are unfounded/unfair and null and void, i.e. loan agreements approved in CHF are absolutely null and void. This results in an obligation under which the defendants undertake to pay the plaintiff the amount of the loan paid, with statutory default interest from the date of filing the lawsuit until payment and to reimburse the costs of the proceedings" [1].

The problem is it has been ten years now since the courts in $\mathrm{BiH}$ have issued the first final judgments that are contrary to the judgments of the Court of Justice (eg C-118/17 and C260/18) and the courts of EU member states in the same/similar legal matter. Therefore, pursuant to Article 203, Article 20 and Article 208, within the legal deadline, the plaintiffs filed appeals against the judgment of the first instance court, for the following reasons: violation of the provisions of the civil procedure; erroneous and incomplete established facts; and misapplication of substantive law.

The main hypothesis of the paper is: after ten years, opposite judgments have been handed down by the courts in relation to the judgments of the Court of Justice of the EU and the courts of the EU Member States in the same / similar legal matter This leads to a violation of Article 70/1 of the $\mathrm{SAA}^{3}$ in terms of Article 3. Chapter VII of the $\mathrm{FBiH}$ Constitution ${ }^{4}$. The courts flagrantly violated the right of the appellants to a fair trial under Art. II / 3.e) of the Constitution of $\mathrm{BiH}$ and Article 6, paragraph 1. ECHR and the right to non-discrimination under Article 14 of the ECHR, and the right to property from Article II / 3.k) of the Constitution of $\mathrm{BiH}$ and Article 1 of the Protocol 1 to the ECHR.

The first working hypothesis of the paper is: the passing of different judgments in relation to the judgments of the EU courts in the same / similar legal matter is based on violations of the provisions of the procedure and arbitrary (non) assessment of the presented facts and evidence.

The second working hypothesis of the paper is: the adoption of different judgments in relation to the judgments of EU courts by regular courts is based on erroneous and incompletely established facts and erroneous application of substantive law.

The purpose of this paper is to develop a nomotechnical

2 Judgment of the Municipal Court in Mostar No. 580 P 10277818 P 2, dated 24 December 2018.

3 Stabilization and Association Agreement between the European Communities and their Member States, of the one part, and $\mathrm{BiH}$, of the other part, OJ L 164, 30.6.2015, p. 2.

4 Constitution of the Federation of Bosnia and Herzegovina, "Official Gazette of the $\mathrm{F} \mathrm{BiH} \mathrm{",} \mathrm{no.:} \mathrm{1/94,} \mathrm{13/97,} \mathrm{16/02,} \mathrm{22/02,} \mathrm{52/02,} \mathrm{63/03,} \mathrm{9/04,} \mathrm{20/04,} \mathrm{33/04,}$ $71 / 05,72 / 05,88 / 08$. module pro bono publico in order to provide legal assistance to the LUs, proxies, creditors, legal representatives, lawyers (for writing complaints/lawsuits-defining the main and subsidiary claims, delimitation and interpretation of necessary financial terms, collection, selection and presentation fact and hearing of relevant evidence) and courts in order to achieve effective protection, rights and interests of the parties in dispute resolution proceedings, arising in the process of fulfilling the contracting in accordance with the judgments of the EU courts.

\section{Violation of the Provisions of Civil Procedure}

Courts, hereinafter the court, violated the provision of Article 57, paragraph 2 of the LCP, when at the main hearing it accepted by a decision the plaintiff's amended claims, harmonized with the expert's finding and opinion, and in the operative part of the judgment it decided on the subject of another claim. In the operative part of the judgment, the court incorrectly determined the sums of money claimed by the plaintiff. By the subsidiary request, the plaintiff claims the amount of. KM and not of. KM in the name of collected exchange rate differences CHF: KM, and the amount of. KM and not of. KM in the name of unjustifiably collected interest or the total amount of. KM and not from. KM, so in the said judgment in the first claim the court did not decide in full on the claim, and in the subsidiary claim there was a quantitative exceeding of the same ${ }^{5}$, and the above violated the provision of Article 57 para. 2. in terms of Article 209. paragraph 2, item 11 of the LCP, and the court, taking into account the stated ground of appeal, decides in accordance with the provisions of Article 227a of the LCP. In addition, by the operative part of the judgment, the court did not decide on the (non) existence of the claim for set-off, but in the reasoning of the judgment (see. Annex 5 to the contract) in the name of strengthening the merits of the argumentation on the rejection of the request of unjustifiably collected interest, it added the alleged set-off which was performed by the annex, which is contrary to Article 191, paragraph 3 of the LCP.

In the remaining part, in relation to both claims, the same remains unchanged, i.e. modified claims are defined and accepted by the court decision in the Minutes of the main hearing ${ }^{6}$, with the fact that in the subsidiary claim the total amount of $103,170.76 \mathrm{KM}$, technical error because after adding the amount on all grounds, the amount of 100,121.28 $\mathrm{KM}$ is obtained. That is, in the Finding and the expert's opinion "this request must be charged by the accounting technique for each unfounded charge individually, and not

\footnotetext{
5 A court that would judge ultra et extra petita, which would go beyond the claim, would commit an absolute violation of the provisions of civil procedure, for which an appeal and (with certain restrictions) revision may be lodged. The claim determines the content of an individual legal norm that the court creates by a decision, as an individual legal act.

6 Minutes No.: 580 P 10277818 P 2 from the main hearing of 15.10 .2018 , p. 5 and 6
} 
overall, so this error is not significant. Accordingly, the judgment does not contain reasons on decisive facts" [2].

The court also violated the provision of Article 3 (2) and in connection with it Article 124 (1) of the LCP when it allowed the defendant and considered the so-called an annex to a contract whose contents are contrary to coercive regulations such as contracting to withdraw a lawsuit under duress and fraud or the so-called the annex was not concluded because it was not signed by the contracting parties in terms of subjective modification of the lawsuit by order of the Cantonal Court in Mostar, Decision No. 580 P 10277815 Gž2.

The court did not order the parties to present evidence that is important for making a decision in terms of Article 124, item (1) of the LCP, but arbitrarily considers the annex as an out-of-court settlement in terms of its own determination of the fact of unjustifiably charged interest of. KM. This means that the court, without assessing the presented evidence and established facts, carried out the set-off between the parties, arbitrarily and contrary to the provisions of Article 86-Article 90 LCP. In fact, the court violated the provisions of Articles 86, 87, 88, 89, 90, 91, 92 and Article 93 of the LCP.

The court also violated the provisions of Article 12 (1) of the LCP when it did not solve the so-called annex as a preliminary issue, but has already unlawfully accepted that the issue has been resolved-by the Decision of the Cantonal Court of 4.7.2017.

The court also violated the provision of Article 74 item (1) of the LCP when it did not instruct the defendant that his requests regarding the settlement and determination of the legal relationship in connection with the so-called annex can only be resolved by a counterclaim, if it has already, unlawfully allowed the assessment of the annex. ${ }^{7}$ "Therefore, in terms of Article 74 paragraph (1) the defendant, in response to the lawsuit, may not make those substantive legal claims that he may put in a counter-lawsuit or in a separate lawsuit," [3] that is, the defendant may file a counterclaim on the response to the lawsuit, and at the latest at the preparatory hearing for the main hearing, if it has not been held or until the conclusion of the main hearing before the court, the defendant may file a counterclaim with the same court, if the counterclaim is related to the claim, or if these claims can be offset, or if the lawsuit seeks to establish any rights or legal relationship) existence depends in whole or in part on the decision on the claim.

The court also violated the provision of Article 107 (1) because it did not reject the request for evaluation of the socalled Annex for the above reasons, i.e. the court violated Article 7, item (2) and Article 8, item (2) and Article 191, item (4) of the LCP, because it did not state in the explanation the relevant facts the plaintiff has stated and the presented evidence; which of these facts the court took into consideration, why and how it established them, certainly not by proving, did not appreciate the presented evidence and did not conscientiously and carefully evaluate each piece of

7 Annex to the loan agreement with the currency clause in CHF no. 1637297196 dated 29 April 2008. evidence separately and all evidence together. That is, the court did not determine, although the plaintiff proved: the adhesive technique of the contract; and did not determine whether the defendant informed the plaintiff of the risks associated with the CHF: KM exchange rate; and did not determine whether the defendant had a CHF in his foreign currency account when he granted the plaintiff a loan in CHF; and did not determine whether a foreign currency loan in $\mathrm{CHF}$ or a loan in local currency KM was approved; and has not determined whether it is a currency clause in CHF or a foreign exchange clause in $\mathrm{CHF}$; and, did not appreciate the merits of contracting a currency clause in $\mathrm{CHF}$, given that in the currency legislation of $\mathrm{BiH}$ the exchange rate of $\mathrm{KM}$ is fixed for the Euro. "Many experts believe that the "defection" of capital in CHF was planned by the world's financial institutions, such as the Swiss Ibank UBS and AIG. According to these claims, loans fixed in CHF could be considered an extraordinary means of achieving unacceptable debt bondage goals. "[4] Given that the defendant did not place a loan by converting CHF to KM but from deposits of citizens in $\mathrm{KM}$; and did not determine whether the defendant borrowed CHF abroad or placed the loan from a citizen's deposit in KM; and has not determined whether the price of the loan is determined or determinable; and did not appreciate at all the application of the "principle of equality of the parties in the obligatory relations referred to in Article 11; equal values of mutual benefits referred to in Article 15 and the principles of conscientiousness and honesty from Article 12 of the Law on obligatory relations" [5], i.e. they did not appreciate the disputed contracts through the general clause of (dis) fairness.

Namely, Articles 93 to 95 of the Consumer Protection Law (CPL) and Articles 70 to 73 of the LOR essentially regulate the general clause of unfairness of certain provisions of the general conditions in the same way by prescribing that a "clause that is contrary to the principle of conscientiousness and honesty causes a significant imbalance in the rights and obligations of the contracting parties to the detriment of consumers "[6]. And the sanction for that clause is identicalabsolutely null and void contracts. The general dishonesty clause is composed of two criteria that must be cumulatively met. In the legal literature, the criterion of obvious inequality in the rights and obligations of the parties to the detriment of consumers is generally considered fundamental, but what is considered a "significant imbalance" [7] is not defined neither by Directive 93/13/EEC or LOR and CPL. This is to be decided by the court in each particular case.

\section{Wrong and Incompletely Established Factual Situation and Wrong Application of Substantive Law}

\subsection{Wrongly and Incompletely Established Dispute Between the Parties}

On p. 10. of the judgement the court arbitrarily, per se and 
erroneously states that: "It is disputable between the parties whether the loan agreement, has the character of a foreign exchange agreement or a loan with a CHF currency clause and whether such agreements are allowed or null and void" [8].

Nowhere did the plaintiff claim that it was a foreign exchange contract, not even the defendant, but the plaintiff in the lawsuit and all his submissions and statements and the expert in the finding and opinion and in the statements at the hearing, they claimed that it was a foreign currency loan, and the defendant claimed that it was a loan in KM with a currency clause in CHF. Thus, the dispute between the parties is: whether or not the approved foreign currency loan is in CHF, i.e. is or is it not the approved a loan in KM with a currency clause in CHF. If a foreign currency loan was approved, then it was forbidden to a natural person in terms of Article 56 of the FBiH Law on Foreign Currency from 1998, but if a loan in KM with a currency clause in CHF was approved, then contracting a currency clause in $\mathrm{CHF}$ is unfounded and null and void. This means that if the court finds that a foreign currency loan has been approved, then it must accept the first claim, or if the court finds that a loan in $\mathrm{KM}$ with a currency clause in CHF has been approved, then it must accept a subsidiary claim, i.e. the court cannot reject both claims, as it does.

Following the above, the dispute can only be properly resolved by properly assessing the provisions of Article 56 of Law on Foreign Currency and/or by assessing the evidence presented, first by expertise and not by arbitrary assessment of the content of the contractual obligations of the debtor in the loan agreement, which the court did. Consequently, the court arbitrarily applies on p. 11. the current legal provisions as follows: "At the time of concluding the loan agreement, the 1998 Law on Foreign Currency was in force, which by the provision of Article 56 stipulates that banks may grant foreign currency loans to domestic legal entities for the purpose of payment abroad, provided that interest in foreign currency may be paid on the approved foreign currency loan. In terms of this provision, foreign currency loans are granted to domestic legal entities in foreign currency and are repaid in foreign currency" [8].

As the plaintiff is a natural and not a legal entity, the court in this part misapplied the substantive law by misinterpreting the cited provision of Article 56 of the Law on Foreign Currency in the last sentence when concluding that the foreign currency loan, i.e. that it is repaid in foreign currency, because, in the cited provision, it is about the possibility"interest can be paid in foreign currency..." which means the first payment of interest in KM and only then in foreign currency since KM is the domestic currency.

The cited provision of the Law on Foreign Currency from 1998 defines the term "foreign currency loan (FCL)", in a way that explicitly lists two main (un) important legal elements of that term, namely: approval of FCL and payment of interest on the approved FCL. Thus, the cited provision of the Law on Foreign Currency stipulates that the explicit element of the term "FCL" is the approval of FCL, which obliges the creditor to make available to the debtor the approved mass of foreign currency (on a foreign currency account or foreign currency savings book or sale of foreign currency for the currency CHF for KM), while the explicit element of the term "FCL" payment of interest is irrelevant. FCL with regard to the payment of interest is the loan on which interest is paid in $\mathrm{KM}$, with the provision that you can also pay interest in foreign currency, therefore, the opposite conclusion from the conclusion of the court.

Given that interest on approved FCL can be paid to legal entities, both in KM and in foreign currency, this means that the currency in which interest is paid on the loan does not define the term "foreign currency loan", because then approved loan in CHF would be and both foreign currency and KM loan, if necessary, as the court does, which is impossible. Therefore, only the currency in which the loan is approved, which is CHF, determines the foreign exchange nature of the loan. This is the only valid implied definition of the term "foreign currency loan" and is found in Article 56 of the Law on Foreign Currency. This definition is also objectified by the statements of the financial expert and his findings and opinion on the content of the contract, which proves that it is a FCL and not a loan in local currency KM with a currency clause in CHF since the loan was approved in $\mathrm{CHF}$ and a monetary obligation plaintiff reads CHF.

The fact that the mass of approved CHFs was not placed on the plaintiff's account, but the conversion of CHF into KM was made at the plaintiff's request, considering that the plaintiff bought the apartment in $\mathrm{KM}$ or that the loan is repaid in $\mathrm{KM}$ is not important for determining the property of FCL because every citizen can pay any of his financial obligations in any currency, eg CHF, $\$, \mathrm{KM}, €$ in $\mathrm{KM}$, for the simple reason that the purpose of the banks is to enable everyone to pay their obligations in the currency they have. This is done by the bank by payment technique or exchange of $\mathrm{KM}$ for $\mathrm{CHF}$, at the selling rate, of course with a commission. Likewise, a citizen can pay his obligation in CHF, eg. using $\$$ that he hid in a mattress, by exchanging that currency for $\mathrm{CHF}$ at the selling rate. Or LU can buy an apartment by paying in KM, regardless of the fact that the loan was approved in CHF, because he simply, at his own will or need, converted his CHF for KM. So, it is a payment technique that understands payment in every currency that the client has and therefore it can not determine the nature of the approved loan, but CHF currency in which the loan is approved, which arises from Article 56 of the Law on Foreign Currency and is consistent with Article 394 of the LOR and reads: "When the obligation has as its object the amount of money, the debtor is obliged to pay the number of monetary units to which the obligation relates, except when the law determines otherwise" [5]. The obligation of the debtor is CHF. This means that the debtor is obliged to pay the number of $\mathrm{CHF}$ monetary units granted to him and not the number of $\mathrm{KM}$ monetary units by which the obligation in $\mathrm{CHF}$ is paid.

Furthermore, the term "debtor's obligation" and the term "debtor's payment" are two different terms in banking. The term "payment" is a technique of performing a monetary obligation of the debtor. This means that the client of each 
bank can fulfill his financial obligation by paying in any currency, regardless of whether the obligation is in CHF or $€$. In that sense, the plaintiff chose to pay in $\mathrm{KM}$, using the $\mathrm{CHF}$ to KM conversion technique, and he could have done so in another currency. That is, the plaintiff can always change the currency of loan payment because, for example, he has no more salary in KM but has $€$ from the sale of the land he inherited in the probate proceedings, then according to the court's conclusion, he would conclude that it is FCL. After all, the bank could activate the mortgage if the plaintiff does not pay the monetary obligation in KM and, it is then a payment in terms of settling the obligation that reads CHF. Therefore, the technique of paying the loan obligation in KM cannot determine the nature of the approved loan, as the court claims

Although it is evidentiary and not yet the subject of dispute, the court, without assessing the evidence presented by the expert, incorrectly and arbitrarily and contradictorily concluded on page 11 of the judgment, as follows: "Although the loan agreement does not state that a loan is placed in KM currency and that the loan installment is paid in local currency, it is concluded that it is a loan with a currency clause, and not a foreign currency loan, as follows from the aforementioned Decision of the Supreme Court" [9].

First, the court incorrectly concludes that it is a loan with a currency clause and not a FCL, because this conclusion is contradictory per se given that it concludes on the nature of two different objects of conclusion as one. The court had to decide, firstly, which safeguard clause it was-a foreign exchange clause in CHF or a currency clause in CHF, and secondly-whether FCL in $\mathrm{CHF}$ or a loan in $\mathrm{KM}$ was approved. Instead, the court is called upon to draw a conclusion based on the Decision of the Supreme Court of the FBiH.

\subsection{Decision of the Supreme Court of the Federation of Bosnia and Herzegovina}

The Municipal Court in Mostar submitted to the Supreme Court of the $\mathrm{F} \mathrm{BiH}$ a request to initiate proceedings to resolve a number of disputed legal issues arising from cases related to CHF loan agreements. After the answer to the lawsuit of the defendant bank was given, the court canceled the preparatory hearing and stopped the procedure until the decision of this court on the submitted request. The request states that a number of lawsuits of CHF loan users were filed before that court against the defendant bank, which is essentially based on an almost identical factual and legal basis, but on which there are different views of that court. These are cases in which the following legal issues arise as disputable:

1. Are the loan agreements in foreign currency given that they are approved in CHF currency, principal debt, annuities, repayment plan denominated in foreign currency or are they contracts with a currency clause because the approved loan amount is paid in local currency and the loan is also repaid in domestic currency and whether the conclusion of such contracts is allowed;

2. Is a contractual obligation of the borrower to pay a variable interest rate indefinite and indeterminate in terms of
Article 46 of the LOR;

3. Do such contractual provisions in the sense of Article 100 of the LOR represent vague provisions as to why the contracts of the parties are null and void.

The Supreme Court of the $\mathrm{F} \mathrm{BiH}$ in Sarajevo, deciding on the request of the Municipal Court in Mostar to resolve disputed legal issues dated 31.03.2016, based on the provision of Article 61 of the LCP and the provisions of Article 18 Rulebook on Internal Judicial Operations of $\mathrm{F} \mathrm{BiH}$ and Brcko District, ${ }^{8}$ at the session of the Civil Department held on 25.05.2016, issued a decision approving the request of the Municipal Court in Mostar to resolve the first two disputed legal issues (while the request to resolve the third disputed legal issue was rejected by the court) so the Civil Division of the Supreme Court of the $\mathrm{F} \mathrm{BiH}$ expresses the following legal understandings: ${ }^{9}$

1. Loan agreements concluded between individuals and banks in CHF, whose payment is made in $\mathrm{KM}$, in which currency the annuity is repaid and interest is paid, are agreements with a currency clause.

2. The Law on Foreign Exchange Operations in the $\mathrm{FBiH}$ provides for the possibility of concluding such agreements between domestic natural persons and banks, so it is not a null and void legal transaction in the sense of Articles 103 and 105 of the Law on Obligations.

3. The provision of the Loan Agreement relating to the variable interest rate that contains the exact definition of the fixed and variable part of the interest rate is sufficiently determinable from the aspect of the subject of the obligation, so it does not constitute a null and void provision in terms of Article 47 of the LOR. (.)

In general, the decision of the Supreme Court of FBiH does not refer to resolving the dispute between the parties, namely: whether FCL in CHF or a loan in KM was approved with a currency clause $\mathrm{CHF}$, but refers to the nature of the loan agreement, which is not even disputed. In addition, the decision of the Supreme Court refers to a specific request ${ }^{10}$, so it cannot be generalized in a lump sum. The Supreme Court concluded only on the basis of the 1998 LFEO, although the law does not explicitly regulate this; that it is permissible to contract a currency clause in the CHF until it has assessed the 2010 Law on Foreign Currency (LoFC) ${ }^{11}$ and the CPL at all, i.e. the Supreme Court, based on Article 394 and Article 395 of the LOR issues 22 years ago, took the opposite position according to which "a license for contracting a currency

\footnotetext{
8 ,Official Gazette of $\mathrm{BiH}$ ", No. 66/12 and 40/14.

9Legal understandings are engaged in order to ensure the uniform application of the law and equality of all in its application. The first-instance court gave its own interpretation of the disputed legal issues, expressing the position that it was a loan with a currency clause, the conclusion of which was allowed, that the plaintiff's obligation regarding the variable interest rate is indefinite and indeterminate because there are not enough elements of which certain provisions of the loan agreement are null and void from the aspect of the provision of Article 4 of the LOR, that during the contract the defendant arbitrarily changed the interest rate to the detriment of the plaintiff in accordance with its decisions which the plaintiffs could not influence and which were not available to them.

10 Request of the Municipal Court in Mostar no. 58 o P135023 16 P. 11 Law on Foreign Currency (LoFC), Official Gazette of the FBiH, No. 47/10.
} 
clause should be regulated by a special regulation and that in the absence of such a regulation, contracting a currency clause is not allowed" Therefore, the court has two concrete and opposite positions, so it must resolve it in accordance with the practice of EU courts.

In addition, according to the rules of logic, the court incorrectly concludes that "Loan agreements concluded between natural persons and banks in CHF, whose payment is made in KM, in which currency the annuity is paid and interest is paid, are contracts with a currency clause." [10]. The logical question is how come the court did not find that it was a loan agreement with a variable interest rate clause, given that this clause also exists in the agreement. The name of the disputed agreement is "Loan Agreement" and not "Agreement or Loan with a Currency or Foreign Exchange Clause or" Foreign Exchange Agreement "or" Loan Agreement with a Variable Interest Rate Clause.

In the end, the Municipal Court in Mostar did not act on the order of the Mostar County Court, because it did not appreciate the evidence, which the court pointed out in the reasoning of the decision, as an expert's failure to clarify " which important elements in banking determine the characteristics of FCL, i.e. a loan in local currency linked to a currency clause, whether it is the currency in which the loan is granted or the currency in which the loan is repaid, and whether, for a loan linked to a currency clause, it is assumed to be approved in that currency. All these dilemmas will be removed by the first instance court in the retrial in order to correctly establish the relevant facts" [10].

Although the expert witness corrected the presented omission, the court did not appreciate the evidence. The expert's report states: "Despite the fact that the loan is placed in KM currency and that the repayment is made in KM currency from the documentation accompanying this loan (Loan Agreement, Loan Repayment Plan, Bank Statements and other correspondence), it can be seen that all documents are related to the CHF currency and it can be stated that the basic contract has elements of a foreign exchange contract" [11]. In support of the expert's opinion that contracts with a currency clause are foreign exchange contracts, the statement in response to the lawsuit of 22.02.12., in which on p. 3. states the following: "Article 28 of the LoFC stipulates that domestic natural persons may keep all foreign currency in a foreign currency account or foreign currency savings deposit or sell them to a bank, which is analogous to the loan relationship in question, because the LU voluntarily decided that CHF shall be transferred to his account in KM, with a currency clause at the middle exchange rate on the day of concluding the contract The Bank approved foreign currency funds that the client could deposit in a foreign currency account or in a foreign currency savings account, but at his request clause conversion at the middle exchange rate on the day of concluding the contract in KM currency ". This is, therefore, the opposite conclusion in relation to the controversial conclusion of the court. The presented evidence was objectified by the answer of the financial expert to the question of the plaintiff's attorney at the main hearing, which reads:
1. Is the currency in which the loan is approved or the currency in which the loan is placed and repaid determined by the characteristics of a foreign currency loan or a loan in local currency? A: The currency in which the loan is approved determines the characteristics of the foreign currency loan, i.e. the loan in local currency!

2. Is a loan linked to a currency clause in CHF understood to be approved in CHF? A: Yes!

In the procedure, it has been proven that there is a definition of FCL in Article 56 of the LoFC, which is only relevant, because the court makes a decision on the basis of the law and the established facts and not as a lump sum. Based on this, a single conclusion can be drawn, and that is: that the plaintiff as a natural person was unlawfully granted FCL in CHF. Therefore, the Decision on approving the defendant's loan ${ }^{12}$ and the disputed contracts are in Article 1, Article 2, Article 11 and Art. 12. of the loan agreement are null and void, i.e. the contract is null and void in terms of Article 103 of the Law on Obligatory Relations.

\subsection{Wrong Application of the Provisions of Currency Legislation}

On p. 12. pas. 1. of the judgment, the court concludes, without assessing the evidence, arbitrarily, as follows: "Thus, the provisions of the $L O F C$, as well as the $C B L^{13}$ and Law on Banks ${ }^{14}$, did not prohibit contracting in foreign currency with a foreign exchange clause linked to the CHF. [...] From the previous legal provisions as well as the provisions of Article 395 of the LOR, can be concluded that contracting a loan with a currency clause was not prohibited at the time of concluding the contract" [8]. In the cited text, the court erroneously and controversially concludes that contracting in foreign currency with a foreign exchange clause related to CHF was not prohibited and everywhere in the judgment it cites the Supreme Court Decision as a loan agreement with a currency clause in CHF. Obvious conceptual confusion necessarily leads to erroneous conclusions. The foreign exchange clause in $\mathrm{CHF}$ and the currency clause in CHF are two different clauses such as, foreign currency loan in $\mathrm{CHF}$ and loan in local currency $\mathrm{KM}$ are two different loans. Foreign exchange clauses in CHF for the subject of payment have monetary obligations denominated in foreign currency $\mathrm{CH}$, while currency clauses in $\mathrm{CHF}$ for the subject of payment have monetary obligations denominated in domestic currency KM, and fulfillment of monetary obligation, calculation of the number of loan installment payments is indexed for the exchange rate $\mathrm{CHF}$. At the time of concluding the contract, it was not allowed to approve FCL to natural persons and to contract a currency clause in the sense of Article 56 of the LoFC. This decision was repealed by Article 5 of the LoFC from 2010, it is allowed to contract in foreign

12 Decision from the 16th session of the Senior Credit Committee of the Retail Department, Hypo Alpe-Adria bank d.d. Mostar, April 28, 2008.

13 Law on the Central Bank of BiH, "Official Gazette of BiH "no. 1/97, 29/02, $8 / 03,9 / 05,76 / 06$ and 32/07.

14 Law on Banks, "Official Gazette of the FBiH, "no.: 39/98, 32/00, 48/01, 41/02, $58 / 02,19 / 03$ and 28/03. 
currency and with natural persons, with the payment and collection being made in KM. However, at the time of the contract, the amended provision was not valid and could not be applied retroactively. Contracting a currency clause in $\mathrm{CHF}$ is not allowed according to the obligation from paragraph 1. in terms of paragraph 3 of Article 395 of the Law on Obligations, given that the plaintiff's financial obligation contrary to Article 56 of the LoFC is CHF, and then its fulfillment can be required only in local currency according to the selling rate valid on the day of placing the loan on plaintiff's account. This means that it is not allowed to contract a currency clause in CHF, because then the cited legal provisions cannot but be violated, simply because the exchange rate CHF: KM is variable. The loan repayment showed that an unpredictable number of KM monetary units had to be paid in installments in the loan installment until the contract was fulfilled. "By the court decision, the illegally contracted currency clause will be reduced to the framework of the law, i.e. to the framework of the above-mentioned coercive norm which stipulates that payment in gold or some foreign currency can be requested only in domestic money at the exchange rate valid at the time of the obligation " [12].

\subsection{Violation of Article 70/1 of the $S A A^{15}$}

On p. 11 of the judgment the court without an assessment of case law and evidence, and on the basis of unfounded reference to the decision of the supreme court erroneously concludes the following "it follows from the foregoing that the subject of the obligation is determinable because the contract contains data by which it can be determined in terms of article 50 paragraph (1) of the LOR, which was also determined by the supreme court by a decision which resolved the disputed legal issue, and the decision is binding on this court. That is why the court concludes that there are no reasons to determine the loan agreement as null and void in the sense of article 46 of the law obligations".

The erroneous conclusion of the court is reasoned ahead in the sense that the court unreasonably invokes the Decision of the Supreme Court. In addition, all courts in $\mathrm{BiH}$, including the Supreme Court, are obliged to implement the obligation of stronger legal force and hierarchy, in terms of Article 3 of Chapter VII of the Constitution of the $\mathrm{FBiH}$, which reads: In case of disagreement between the international agreement and the legislation, the international agreement prevails. In the cited sense, the provision in Article 70/1 of the SAA represents a provision of an international agreement in relation to the Decision of the Supreme Court, and reads: "BiH will ensure the proper implementation and enforcement of existing and future legislation." This means that $\mathrm{BiH}$ will properly implement the law, not only by formally enacting new regulations, but also by interpreting existing regulations, in line with the interpretative effect expressed in EU court rulings.

15 Stabilization and Association Agreement between the European Communities and their Member States, of the one part, and $\mathrm{BiH}$, of the other part (OJ L 164, 30.6.2015, p. 2).
This obligation means that the court is obliged to apply to this dispute, not arbitrary interpretations of existing regulations, but interpretations of these regulations in accordance with the interpretive effect expressed in the case law of EU courts. ${ }^{16}$ "It can therefore be concluded that the SAA has an obligation for courts to interpret domestic law in line with European law" [13]. This means that the judgment of the court should be in accordance with, for example, judgments in which the EU Court ${ }^{17}$ ruled that the currency clause in CHF is unfair and the legal basis for the nullity of the loan agreement because it violates the principle of balance, conscientiousness and fairness because no individual negotiations were conducted on the disputed contracts and, because the LUs were not aware of the currency risk, the contracts were vaguely and incomprehensibly settled.

The nullity of the currency clause and the nullity of the agreed interest rate were also ruled by the Commercial Court in Zagreb ${ }^{18}$, which was confirmed by the High Commercial Court of the Republic of Croatia ${ }^{19}$, the Supreme Court of the Republic of Croatia in its revisions ${ }^{20}$ confirmed that these were null and void contracts and not that there was partial nullity of contracts with a currency clause in CHF.

\subsection{Wrongly and Incompletely Established Fact That the Subject of the Obligation Is Determinable}

The court's conclusion that the subject of the obligation is determinable is erroneous because the contract contains data by which it can be determined in terms of Article 50 paragraph 1 of the LOR for the following reasons: It is obvious from reading the contract that the loan price cannot be determined because there is no data in the contract what is the interest margin. Considering that the subject of the obligation is the repayment of the placed loan amount and the agreed interest, and then the interest margin had to be determined or determined in the contract, both regarding the main debt and the interest margin in terms of Article 1065 of the Law on Obligations.

According to Article 50, paragraph 1 of the Law on Obligations" the price of a loan is determined if, when concluding the contract, it is known what and how much is the plaintiff's financial obligation at the time of fulfillment, how much is the installment during the loan repayment. The price is determinable if it is not fully or partially determined but can be determined subsequently using the information contained in the contract, or the contracting parties have left

$16 \mathrm{As} \mathrm{BiH}$ is not yet a member of the $\mathrm{EU}$, the answer to the question of whether courts can take EU law into account when interpreting law is a matter of internal constitutional order, not European. Given that the SAA (international treaty) has entered into force, the courts in (F) $\mathrm{BiH}$ are obliged to implement the obligation of stronger legal force and hierarchy, in terms of Article 3 of Chapter VII of the FBiH Constitution.

17 Judgment of the Court of Justice of the EU in case C-119/17, and C-126/17. 18 Judgment of the Commercial Court in Zagreb, No.: P-1401/12 of 4 July 2013. 19 Judgment of the High Commercial Court of the Republic of Croatia, no.: 43 Pž-6632/2017-10.

20 Judgment of the Supreme Court of the Republic of Croatia no.: 870/01, 899/06, $1743 / 11,556 / 10$ and $1970 / 11$ as well as $907 / 02$ and $111 / 16$. 
it to third parties to determine the price."

Viewed from the cited legal solution, it is obvious from the paid installments of the loan that it is not known how much installment is in the course of loan repayment, nor is it known from the repayment plan of the defendant. The price of the loan is not determined in the contract, nor can it be determined from the data contained in the contract. The defendant's repayment plans do not specify or determine the price (installment) of the loan, but the monetary obligation that reads $\mathrm{CHF}^{21}$. Since this monetary obligation is paid in $\mathrm{KM}$, then the number of KM monetary units paid for the loan represents the price of the loan. However, due to the exchange rate difference CHF: KM, the number of monetary units KM paid by the plaintiff from installment to installment of the loan for the performance of the monetary obligation in $\mathrm{CHF}^{22}$ is different. Therefore, it is not possible to determine the price of the loan because the defendant in the contract, which could not be influenced by the plaintiff, determined for himself the exclusive right to unilaterally determine the interest margin in Article 11 of the contract, internal decisions, which is contrary to Article 50 paragraph 1 of the LOR. ${ }^{23}$

Also in the provisions of Article 1066 of the LRO stipulates that the loan agreement must be made in writing, while the provisions of paragraph 2 of the same article stipulates that the loan agreement determines the amount, as well as the conditions for granting, using and repaying the loan. Thus, among other things, "terms of use and repayment of the loan" are an essential element of the loan agreement, without which the agreement cannot survive. This means that the interest margin had to be determined by the contract or annex to the contract and not as the court erroneously concludes that there are determinable data in the contract by the defendant determining for himself the exclusive right to unilaterally determine the interest margin by internal decisions in Art. 11 of the Contract. Thus, it is logical that the margin on interest cannot be determined for the plaintiff according to the information on the plaintiff's notice when the defendant determines it himself. The plaintiff's notification of the determination of the interest margin is not a data in the contract on the basis of which he could determine the margin, but a notification that the defendant independently and incognito determined the margin by an internal decision. This means that the plaintiff cannot determine the margin but only (not) receive notification of a certain margin.

The consequence of the exclusive right to unilaterally

21 Internal order - loan placement with foreign exchange clause from 30.05.2008; Loan repayment plan from 30.05.2008; and Debt balance certificate and payment review number: 15-01 / 14-92 dated 13 March 2014.

22 Review of changes per lot number: 163729196, No.: 15-01/14 - 92, dated March 17 2014, Hypo-Alpe Adria Bank d.d. Mostar.

23 Decision on determining the amount of interest rate (KS) on special-purpose housing loans with a currency clause in CHF, Hypo-Alpe-Adria-Bank d.d. Mostar, 1.10.2011; Decision on interest rates in retail banking, No.: U-153-05 / 06-1 of 15.05.2006. and Decision on Amendments to the Decision on Interest Rates in Retail Banking (second consolidated text), number: U-137-01 / 06-18, Mostar, January 23, 2006. determine the interest margin is evidence in the finding and opinion of the expert, which was accepted by the court, that the defendant changed the margin only according to his interest and was obliged to call the plaintiff before the change of interest rate, and conclude with him an annex to the contract to change the margin, and it is not. In cases where the libor rate fell, the defendant made decisions to increase the margin rate by the same $\%$ point, of which he did not inform the plaintiff.

The report of the court expert states: "The bank regularly, semi-annually and annually, made decisions on determining the amount of the 12-month libor rate and decisions on changing the Euribor and Libor on credit in the retail portfolio. That is how, on January 20 2009, it passed a Decision on the change of Euribor and Libor to a loan in the retail portfolio, which states, inter alia, for all long-term loans with a variable interest rate placed from 06.03.2005. to 31.12.2008, in the period from 01.01. to 31.12.2009, the 12month Euribor and Libor determined on 31.12.2008 will be applied. Interest margins for loans whose interest rates are determined on the basis of 12-month Euribor are increased by $1.50 \%$ points, and interest margins for loans whose interest rates are determined on the basis of 12-month Libor are increased by $1.75 \%$ points. "[11]. The margin is an integral part of the interest rate and constitutes an essential component of the contract, and it does not state that it is an integral part of the credit committee's decision as wrongly accepted by the court.

The margin is determined and changed exclusively by the consent of the will of both contracting parties in terms of Article 26 of the LOR. This article prescribes: "... a contract is concluded when the contracting parties have agreed on the essential components of the contract". Specifically, this means when the plaintiff and the defendant have agreed on a margin. Thus, it is not prescribed that the plaintiff and the defendant agreed on a contract under which the defendant has the exclusive right to determine the margin by his decisions, which the plaintiff could not influence.

Following the above and in the conducted evidentiary procedure, the plaintiff has proved that the contracting of a variable interest rate fixed by the provisions of the contract is inadmissible and null and void, which the court did not accept or appreciate. As null and void contracting is essential component of the agreement, then the loan agreement is null and void in terms of Article 46 of the LOR.

\section{Unjustified Charging of Exchange Rate Differences}

Pages 14 and 15 of the judgment state: "The court finds that the part of the claim by which the plaintiffs request payment of the amount in the name of exchange rate differences is not grounded. [.] The court does not find grounded the plaintiff's claim that in the case of a contract with a currency clause, the obligation must be determined at the exchange rate on the day of concluding the loan 
agreement, i.e. that day is considered the due date of each monthly loan." [8].

The cited position of the court is, firstly, erroneous because the subsidiary claim for unjustifiably charged exchange rate differences CHF: KM was erroneously established. Second, the court had to assess the merits of this request bearing in mind the necessary fulfillment of the conditions for contracting a currency clause in CHF and that is its protective purpose of the value of the money in which the KM loan was placed. Thus, instead of the court establishing the facts according to which the defendant had to have funds in $\mathrm{CHF}$ to place the loan, the court incorrectly considers the claim by assessing the contracting content of the debtor's obligation in the contract as well as assessing the objective admissibility of contracting a currency clause, i.e. currency clause in $\mathrm{CHF}$ can be allowed in objective law without being contracted contrary to the purpose. This means that the currency value protection condition to contract a currency clause in CHF is not met. Therefore, it is illegal because it violates the principles of equality of the parties in obligatory relations in the sense of Article 11 of the Law on Obligations; equal values of mutual benefits in terms of the provisions of Article 155 of the Law on Obligations; principles of conscientiousness and honesty from Article 12 of the Law on OR.

The expert's finding and opinion proved the fact that the defendant did not have CHF in his foreign currency account CHF in 2008, when it approved a loan to the plaintiff in the amount of CHF 165,300.00. Moreover, it has been proven that the defendant did not have any coverage in CHF of funds placed in $\mathrm{KM}$ for housing loans in $\mathrm{BiH}$, because the defendant was informed by a bank from Austria by Message MT S950 dated 12 March 2007 that the transfer of CHF was made, and within two days the defendant reversed that amount of $\mathrm{CHF}^{24}$

In this regard, on p. 14 of the Report, the court expert points out: ,, Despite the fact that the deposits according to the received statements were paid to the defendant in an account abroad kept with the owner's bank in Klagenfurt, these funds did not remain in the defendant's account, rather they are returned to the depositor through other transactions, but on some other basis. This fact can be verified by inspecting the Financial Report for 2007, which shows that the bank as of 31.12.2007. had a total of KM 96.5 million on the account (cash in the treasury of KM 29.8 million, cash on

24 Financial Stability Report, CB BiH, 2007, 2008, 2009, 2010; Foreign exchange position report - matching of assets and liabilities as of 31.03.2006. 31.12.2009; Maturity position report - maturity adjustment of financial assets and financial liabilities as of 31.03.2006. - 31.12.2009; Confirmation of mutual liabilities and receivables based on long-term foreign currency deposits in EUR and CHF between Hypo Alpe-Adria-Bank d.d. Mostar and Hypo Alpe-AdriaBank International AG on 31.12.2007. on the circumstance of the Bank's indebtedness on the world financial market in the currency CHF (original in English with a translation by a court interpreter) 4 documents - 19 pages; Certificate of refinancing from 16.05.2013. (original in English with a translation by a court interpreter); Message MT S950 from 12.03.2007. that the transfer of $\mathrm{CHF}$ was made, and in two days the defendant reversed that amount of CHF from 23.08.2018. the bank with the CBBH KM 58.8 million, current accounts with other banks KM 7.7 million and checks 0.2 million KM). Considering that the defendant did not sell the funds of the received deposits to either the $\mathrm{CBBH}$ or other banks (the bank has no evidence for that), it follows that the defendant did not have real coverage for the placement of loans with a currency clause. This is just about the so-called. "Borrowed position" for a certain period of time. The expert is of the opinion that the defendant had to cover the amount of loans placed with the currency clause in its accounts if it did not sell foreign currency continuously as it approved loans with a currency clause. If the defendant did not sell CHF currency from which to place loans or has no uninterrupted coverage in CHF on the accounts, then it is true that the defendant on loans with a currency clause has no risks due to changes in the CHF exchange rate against KM. "[2].

This means that the defendant only fictitiously approved the loan to the plaintiff in CHF in order to mislead and deceive him about the economic justification of the obligation to pay the loan in CHF and to collect it in KM. This fictitious transaction, the alleged conversion of $\mathrm{CHF}$ into $\mathrm{KM}$, was confirmed by the expert's findings and opinion, as well as the confirmation of the $\mathrm{CBBH}^{25}$ in which it reads:" Inspecting the $C B$ documentation, it was established that in the period of concluding the disputed contract from 2006 to 2008 , the $C B$ did not convert CHF currency into KM at the request of Hypo Bank d.d. Mostar and Hypo Bank a.d. Banja Luka. (.)"

From the presented factual situation, it can only be concluded that the fixed currency clause in CHF is unfounded since the condition of protection of the value of CHF is not fulfilled. The defendant placed a loan from a citizen's deposit in KM. Given that the loan is placed in KM and the risk of falling value of KM does not exist because the Article 2, Article 32 and 33 of the Law on Central Bank (LCB) established a currency board, by which the KM is firmly pegged to $€$ in order to stabilize the KM. Therefore, contracting a currency clause in CHF is unfounded because it is contrary to its protective purpose. "If a certain provision of the contract is in obvious collision with the purpose of the contract thus defined, it is null and void" [7].

\section{Currency Board Is a Currency Clause Established by Law}

The LCB stipulates that the CB will act as a currency board, i.e. a fixed exchange rate link between $€$ and $\mathrm{KM}$ is to cover the risk in $€$. This provides protection against any detrimental impact on the KM. Banks in $\mathrm{BiH}$ are protected from inflation and exchange rate risks. Low inflation and a

25 Letter from the $\mathrm{CB}$ BIH number: 122-25-1-413-2 / 15NG Sarajevo, 30.01.2015. Link: Your number: 46-1115 dated 27 January 2015, sent to the Association KK "Svicarac" Kulina Bana 1070230 Bugojno, on the circumstance that the bank did not have CHF, because if it did then it would have to sell CHF on the foreign exchange market to secure $\mathrm{KM}$ for loans with a currency clause, i.e. the fact that the bank did not buy CHF for KM is confirmed. 
stable exchange rate ${ }^{26}$ are indisputable facts that contracting a currency clause is unfounded and unfair. From the presented factual situation, it can only be concluded that the currency in which the loan was placed $\mathrm{KM}$ is a stable currency and that inflation in $\mathrm{BiH}$ is low and amounts to $0.4 \%$ on a monthly basis (see the $\mathrm{CBBH}$ website). This means that there is no risk of an unstable KM exchange rate. In the Finding and Opinion on p. 13. the expert witness points out that the defendant could not have any risk ${ }^{27}$ based on the change in the exchange rate of $\mathrm{CHF}$ currency in relation to $\mathrm{KM}$ and thus with regard to the currency board or any economic justification for contracting a loan with a currency clause.

In the end, on the same page of the judgement, the court arbitrarily and erroneously points out: "Apart from the above, the amount that the plaintiff is claiming in the name of exchange rate differences, for the period from April 282008 to April 30,2016 is not harmonized with the Finding and the opinion of the financial expert, nor their amendments, and even if the claim is founded in this part, it is unclear to which time period the amount of 88,480.40 KM I/2 refers "[8].

This conclusion of the court is wrong because the plaintiff does not ask on the basis of exchange rate differences CHF: $\mathrm{KM}$ the amount of. KM, as the court claims, but the amount of. KM. This means that the request is in line with the expert's finding and opinion. It is also wrong when the court concludes that it is unclear to which time period the wrong amount of. KM refers, because it can only refer to the entire loan repayment period given that the currency clause is unreasonably contracted contrary to the purpose and that the loan closed, which the expert in addition to the findings and opinions also pointed out. So, there is no period to which the exchange rate difference would refer, but the total amount paid on the basis of the exchange rate for a closed loan, which is proven by the supplement of the findings and expert opinion from 2018. Unfounded and unfair contracting of a currency clause in CHF, necessarily leads to a violation of the principle of equal value of benefits; equality of the parties in obligatory relations and conscientiousness and honesty from the LOR.

\section{Wrong Application of the Principles of Conscientiousness, Honesty and Equality of Parties}

The Court did not at all appreciate the evidence of the necessary application of the principles of the $\mathrm{BiH}$ legal order in relation to the disputed adhesion contracts, in particular the principles of equality or balance of parties in obligations, conscientiousness and fairness and equal value of benefits from the LOR, although EU courts have built standards on this issue based on the application of European consumer protection regulations. In fact, court rulings in $\mathrm{BiH}$ are

26 Financial Stability Report, CB BiH, 2007, 2008, 2009, 2010.

27 Instruction of the Banking Agency of the $\mathrm{F} \mathrm{BiH}$ for the application of the decision on minimum standards for foreign exchange risk management of banks, No.: 01-2-1350-1/03. contrary to these standards and set a precedent. The judgments also violate Article $70 / 1$ of the SAA, in that the court does not implement the obligation to harmonize the interpretative effect of $\mathrm{BiH}$ legislation with EU standards. The courts in $\mathrm{BiH}$ are obliged to apply to this dispute, not arbitrary interpretations that lead to a violation of the principles of the $\mathrm{BiH}$ legal order, but interpretations of the relevant provisions of the CPL and LOR and European regulations interpreted through court judgments of EU courts.

The courts do not analyze the scope of the LOR and CPL on the general conditions of contracts ${ }^{28}$ whose solutions in fact, incorporate solutions of the Directive 93/13 / EEC and which is interpreted in the case law of EU courts. "Due to the fact that most credit agreements with a currency clause in Swiss francs are subject to the CPL, as a regulation in force at the time of concluding these agreements, this analysis states the provisions of that law" [7]. According to Article 94, paragraph 2 of the ZZP, unfair contractual provisions are null and void, and in accordance with Articles 95 and 93, and in connection with Articles 2 and 3, etc. etc. CPL refers to the following proven facts:

1. It was proved in the procedure that no individual negotiations were conducted on the contractual provisions. The court did not appreciate the witness statements on the circumstances of the conclusion of the contract, and other presented evidence, as they allegedly did not have a relevant influence on the court's decision. However, the opposite has been proven. According to Article 94 and in connection with Article 95 of the ZZP, the provisions on which no individual negotiations were conducted are null and void. Either in the case when the contract is concluded according to the preprinted content, or when the contract was otherwise prepared and proposed by one contracting party, the vague provisions will be interpreted in favor of the other party in terms of Article 100 of the LOR. Since it is an encumbrance contract, all its vague provisions will be interpreted in the sense of achieving a fair relationship of mutual benefits, which means that it is necessary to annul the provisions in Articles 1, 2, 11 and 12 of the contract;

2. "The Defendant itself established the right to unilaterally change the provision of the currency clause in CHF in Article 12 of the contract and the right to unilaterally change the provision of the variable interest rate in Article 11 of the contract " [14]. This means "according to Article 94 and in connection with Article 96 under d. of the CPL that these provisions are invalid, null and void, " [15]. i.e. the provision in Article 96 under d) reads: In the general terms and conditions of the formulated contracts, in particular, the provision is not valid:

(.);

d) by which the contracting party provides that the promised act may be amended and deviated from it only taking into account its interest. (.);

28 Council Directive 93/13 / EEC of 5 April 1993 on unfair terms in consumer contracts (OJ 1993 L 95, p. 29) (OJ, Special Croatian Edition, passage 15, part 12, page 24). 
The European Court of Justice has ruled in several cases, such as C-119/17 and C-126/17, that the currency clause in $\mathrm{CHF}$ is unfair and the legal basis for the nullity of a loan agreement.

3. The defendant did not inform the plaintiff about the fictitious contracting of the currency clause and the risks associated with the CHF: KM exchange rate and there is no determination of the type of Libor, no interest margin, etc. Therefore, the contractual provisions are not clearly and understandably drafted.

\subsection{No Individual Negotiations Were Held on the Contractual Provisions}

It has been proved that "no individual negotiations between the parties were conducted on the contractual provisions. Statement of the defendant's expert stated in the Minutes from the main hearing, held on June 10 2014, p. 14. reads: The $L U$ could not influence the amendment of a contract provision. "[16]. From the point of view of European standards included in the cited provisions of the CPA, the assessment of whether certain provisions are unfair relates to the 3 . Council Directive 93/13/EEC, which reads as follows:

1. A contractual provision that has not been individually negotiated is considered unfair if, contrary to the condition of good faith, it causes a significant imbalance in the rights and obligations of the parties, arising from the contract, to the detriment of consumers.

2. It is always considered that a provision has not been individually negotiated if it has been drafted in advance and the consumer has not been able to influence its content, especially in the context of a pre-formulated standard contract.

[.]

3. The annex contains an indicative and non-exhaustive list of provisions that may be considered unfair. "Provisions referred to in Article 3, paragraph 3", contain item 1, subitem i., which reads: "1. Provisions whose object or purpose is: [.] i. the irrevocable obligation of the consumer to provisions which he did not have a real opportunity to become acquainted with before the conclusion of the contract;

[.]"

Article 6 paragraph 1 of the Directive 93/13 provides: 'Member States shall establish that, in a contract concluded by a seller of goods or a service provider with a consumer, unfair provisions are not binding on the consumer under national law,.' This decision is taken over in Article 94, paragraph 1 of the LCP. This means that this court, like other courts in $\mathrm{BiH}$, is obliged to apply the cited provisions of the $\mathrm{CPL}$, as well as the directives.

\subsection{Views of the Court of Justice}

In the presented analysis of the detection of relevant legal provisions as a source of domestic law, one can observe the positions taken by the Court of Justice, i.e. the Court of Justice received the Request (SL), 21/04/2017 in the dispute between OTP Bank, on the one hand and LUs on the other hand, in connection with a request to establish the unfairness of the provisions contained in the loan agreement in CHF, which was disbursed and repaid in $\mathrm{HUF}^{29}$. The request for a preliminary ruling refers to the interpretation of Article 1, paragraph 2, Article 3, paragraph 1. and Article 4 paragraph 2 of the Council Directive 93/13/EEC. The Court (Second Chamber) delivered the Judgment: ECLI: EU: C: 2018: 750, 20.09.2018 in which it ruled:

1. [.]

3. Article 4 (2) of Directive 93/13 must be interpreted as meaning that the requirement for a contractual term to be drafted in plain intelligible language requires financial institutions to provide borrowers with adequate information to enable them to take well-informed and prudent decisions. In that regard, that requirement means that a term relating to the foreign exchange risk must be understood by the consumer both at the formal and grammatical level and also in terms of its actual effects, so that the average consumer, who is reasonably well informed and reasonably observant and circumspect, would not only be aware of the possibility of a depreciation of the national currency in relation to the foreign currency in which the loan was denominated, but would also be able to assess the potentially significant economic consequences of such a term with regard to his financial obligations.

4. Article 4 of Directive $93 / 13$ must be interpreted as requiring that the plainness and intelligibility of the contractual terms be assessed by referring, at the time of conclusion of the contract, to all the circumstances attending the conclusion of the contract and to all the other terms of the contract, notwithstanding that some of those terms have been declared or presumed to be unfair and, accordingly, annulled at a later time by the national legislature.

5. Article 6 (1) and Article 7 (1) of Directive 93/13 must be interpreted as meaning that it is for the national court to identify of its own motion, in the place of the consumer in his capacity as an applicant, any unfairness of a contractual term, provided that it has available to it the legal and factual elements necessary for that task.

In this regard, the plaintiff was not informed of the risks associated with the exchange rate CHF: KM by the defendant. "Given the financial crisis, the defendant knew that the use of $\mathrm{CHF}$ as a safe currency carries significant financial risks, i.e. that there will be a depreciation of the KM and did not introduce the plaintiff. It was proved that the defendant as a professional was familiar with the conclusions of the IMF." [17]. ${ }^{30}$

\subsection{The Views of the Court of Justice Expressed Through the Answers to the Previous Questions}

The Court of Justice of the EU in the already cited Judgment: ECLI: EU: C: 2018: 750, 20.09.2018 answered

29 Decision No. 2/2014, GPJ (Civil Equality Law), Curia (http://www.ib.hu / hu / print / joghat / 22014-szamu-GPJ-hatarozat.

30 This paper explored the effects of EMU on one country, Switzerland. As the target date for EMU approaches, uncertainties surrounding the creation of EMU may lead to a change in investors 'preferences for hard currency assets outside EMU, including CHF. 
the third preliminary question as follows:

By its third question, the referring court asks, in essence, whether Article 4 (2) of Directive 93/13 must be interpreted as meaning that the requirement for contractual terms to be drafted in plain intelligible language entails that the credit institution must provide detailed information about the foreign exchange risk, including a risk analysis in respect of the economic consequences which might arise from a depreciation of the national currency in relation to the foreign currency in which the loan was denominated.

In that regard, although it is for the national court alone to rule on the classification of terms in accordance with the particular circumstances of the case, the fact remains that the Court has jurisdiction to elicit from the provisions of Directive 93/13, in this case the provisions of Article 4 (2) thereof, the criteria that the national court may or must apply when examining a contractual term. ${ }^{31}$

In that regard, in the context of loan contracts denominated in a foreign currency, it is apparent from the Court's case-law that Article 4 (2) of Directive 93/13 must be interpreted as meaning that the requirement for a contractual term to be drafted in plain intelligible language cannot be reduced merely to it being formally and grammatically intelligible. ${ }^{32}$

As regards foreign currency lending, like that at issue in the main proceedings, it must be noted, as the European Systematic Risk Board stated in its Recommendation ESRB/2011/1 of 21 September 2011 on lending in foreign currencies (OJ 2011 C 342, p. 1), that financial institutions must provide borrowers with adequate information to enable them to take well-informed and prudent decisions and should at least encompass the impact on instalments of a severe depreciation of the legal tender of the Member State in which a borrower is domiciled and of an increase of the foreign interest rate (Recommendation A-Risk awareness of borrowers, paragraph 1). ${ }^{33}$

More specifically, the borrower must, first, be clearly informed of the fact that, in entering into a loan agreement denominated in a foreign currency, he is exposing himself to a certain foreign exchange risk which will, potentially, be difficult to bear in the event of a depreciation of the currency in which he receives his income in relation to the foreign currency in which the loan was granted. Second, the seller or supplier, in this case the bank, must be required to set out the possible variations in the exchange rate and the risks inherent in taking out a loan in a foreign currency. ${ }^{34}$

Finally, as stated in the twentieth recital of Directive 93/13, it is important that the consumer should actually be given an opportunity to examine all the terms of the contract. Information, provided in sufficient time before concluding a

31 Judgment of the Court of Justice of the EU: C-96/14, EU: C: 2015: 262, p. 28. 32 See in this regard the Judgment of the Court of Justice of the EU: C-186/16, EU: C: 2017: 703, p. 44.

33 Judgment of the Court of Justice of the EU: C-186/16, EU: C: 2017: 703,p. 49).

34 Judgment of the Court of Justice of the EU: C-186/16 and C: 2017: 703, p. 50 of 20.09.2017, (Andriucic et al). contract, on the terms of the contract and the consequences of concluding it, is of fundamental importance for a consumer in order to decide whether he wishes to be bound by the terms previously drawn up by the seller or supplier. ${ }^{35}$

In the present case, in the light of the foregoing, it is for the referring court to take into account, inter alia, the presence in the loan contract at issue of paragraph 10 thereof, entitled 'Declaration of notification of risk', the wording of which was set out in paragraph 19 of the present judgment, read in conjunction with any additional information provided before the conclusion of that contract. In that last regard, it is apparent from the information before the Court that the borrowers received, inter alia, an additional information sheet relating to the foreign exchange risk, containing examples of specific calculations of the risk in the event of a depreciation of the Hungarian forint in relation to the Swiss franc, which it is nonetheless for the referring court to ascertain.

[.] It was proved that the plaintiff only received general information about the loan, e.g. interest rate, repayment period, liabilities (pledge, guarantors, co-borrower, loan processing fee, intercalary interest, etc.) and did not receive any information regarding exchange rate risk CHF: KM.

\section{Conclusion}

Although the judgments of the Court of Justice of the EU and the courts of the EU member states built a European standard according to which unfounded/unfair and null and void contracts of the currency clause in CHF and variable interest rate clauses in credit agreements in CHF, Decision of the Supreme Court of F BiH no.: 58 0 P 13502316 Spp, dated 25 May 2016, is contrary. Moreover, in accordance with the CPL, the legal understanding expressed in the Supreme Court's decision is in principle binding on the lower courts, so that even after ten years these courts cannot rule in accordance with the judgments of the EU courts.

The decision is legally unfounded because the court did not assess the relevant provisions of the CPL, i.e. the court based on the provision of Article 394 and Article 395 of the LOR adopted 19 years ago, took the opposite position in Judgment no. Pž 35/96 dated 25.02.1997. In addition, all courts in $\mathrm{BiH}$ are obliged to implement the obligation of stronger legal force, in terms of Article 3 of Chapter VII. of the Constitution of the FBiH, which reads: ". In case of disagreement between the international agreement and the legislation, the international agreement prevails." The provision in Article 70/1 of the SAA is a provision of an international agreement in relation to the Decision of the Supreme Court, and reads: "BiH will ensure the proper implementation and enforcement of existing and future legislation." This means that $\mathrm{BiH}$ will properly implement the law, not only formally by adopting new regulations, but also by interpretations of existing regulations, in accordance with the interpretative effect presented in the judgments of the EU courts.

\footnotetext{
35 Judgment of the Court of Justice of the EU: C-26/13 and C: 2014: 282, paragraph 70 of 30 April 2014, (Kásler and Káslerné Rábai).
} 
The position of the Supreme Court that the interest margin is determinable is arbitrary because the contract does not contain the amount of the interest margin. According to Article 50 paragraph 1 of the LOR: "The price is determinable if it is not fully or partially determined or can be determined subsequently using the data contained in the contract..." The contract does not contain information according to which the price of the loan is determinable, but information according to which the defendant has the exclusive right to unilaterally determine the interest margin in Article 11 of the contract. This means that the plaintiff does not have the information to determine the margin or the price of the loan in the contract, but only has the information according to which the defendant has the right to determine the margin, by internal decision, and inform the plaintiff.

The decision of the Supreme Court is conceptually inconsistent and controversial, in the part related to resolving disputes between the parties, namely: whether a foreign currency loan in CHF or a loan in domestic currency KM was approved with a currency clause CHF, i.e. instead of answering these questions The Supreme Court has taken a position on credit agreements in CHF, according to which these agreements represent agreements with a currency clause, which is not even the subject of dispute, but the subject of prominent conceptual confusion.

In principle, the Decision of the Supreme Court as well as other judgments of $\mathrm{BiH}$ courts are not based on the principles of $\mathrm{BiH}$ legal order (European standards) in the process of fulfilling disputed contracts, especially on the principles of equality of parties in mandatory relations from Article 11 of the LOR; equal values of mutual benefits from Article 15 of the LOR and the principle of conscientiousness and honesty from Article 12 of the LOR. They are not based on a general clause on (unfair) contractual provisions, e.g. in the sense of Article 100 of the LOR all its vague provisions will be interpreted in the sense in which a fair relationship of mutual benefits is achieved, for which it is necessary to annul the provisions in Article 11 and 12 of the contract, i.e. since it is a consumer contract with a currency clause in $\mathrm{CHF}$, this means in terms of Article 94 and in connection with Article 96 under $\mathrm{d}$. CPL that these provisions are invalid and null and void. The provision in Article 96. under d) reads: In the general terms and conditions of the formulated contracts, the provision is not particularly valid:

(.);

d) by which the contracting party provides that the promised act may be amended and withdrawn only taking into account its interest. (.). This means that the provisions of Article 1, Article 2 and in particular Article 11 and Article 12 of the contract, unfair and null and void. From the point of view of European standards that are included in the cited provisions of the CPL, the assessment of whether some provisions are unfair refers to the assessment of the disputed contractual provisions on the basis of the decision of Article 3 of the Council Directive 93/13/EEC, which reads as follows:

1. A contractual provision that has not been individually negotiated is considered unfair if, contrary to the condition of good faith, it causes a significant imbalance in the rights and obligations of the parties, arising from the contract, to the detriment of consumers.

2. A provision shall always be deemed not to have been individually negotiated if it has been drawn up in advance and the consumer has not been able to influence its content, in particular in the context of a pre-formulated model contract.

The decision of the Supreme Court as well as other judgments of $\mathrm{BiH}$ courts are not based on relevant facts and evidence. In fact, as far as factual issues are concerned, the first instance court was obliged to establish this in the reasoning of the judgements and it did not, although the plaintiffs proved, especially with the expert's findings and opinion: that the currency clause in CHF was unfounded and unfairly contracted, considering that the bank in Article 1 and Article 2 and in particular Article 11 and Article 12 of the contract determined that it could unilaterally change the promised act and deviate from it only taking into account its interest. All the more unfair, that LU could not negotiate on unfair contracting individually and that the defendant approved a foreign currency loan (FCL) in CHF fictitiously (it did not have a CHF account but placed a loan from a citizen's deposit in $K M$ ), i.e. that contracting a currency clause in CHF contrary to (the purpose of) the provisions of Article 395 paragraphs 1 and 2 of the LOR and thus prohibited in terms of Article 13 of the LOR. Then the court did not find that the borrower (LU) was not informed about the risks of the CHF: KM exchange rate. Finally, the courts did not appreciate, let alone find, the unfairly agreed variable interest rate clause in Article 11 of the contract, given that this contracting enabled the defendant to unilaterally change the interest rate, which it did, and i.e. it was proven twice, by the findings and opinion of the expert (2014 and 2018).

Contrary to the unlawful conduct of the domestic courts, in failing to establish the relevant factual basis, by interpreting Directive 93/13/EEC, the EU Court of Justice has taken the position that national courts are obliged to examine the unfairness of a contractual provision ex officio (Case C168/05; C-473 / 00; C-243/08; and case C-76/10). ${ }^{36}$ But how will the Supreme and Lower Courts enforce this obligation when they have not at all assessed whether the contract in question has the character of a consumer law contract as well. This means that the courts have not established a valid legal basis for resolving disputes based on the $\mathrm{CPL}$ in $\mathrm{BiH}$.

The presented bad practice of regular courts is a consequence of the lack of personal financial literacy as a subjective presumption and violation of the provisions of civil procedure and erroneous and incomplete determination of the facts. There is a violation of Article 70/1 of the SAA in terms of Article 3 Chapter VII of the Constitution of the Federation of $\mathrm{BiH}$, i.e. there is a violation of the right to a fair trial under Article II/3.e) of the Constitution of $\mathrm{BiH}$ and Article 6 of the ECHR, namely:

36 This position of the court is in line with the concept of protecting consumers from unfair provisions in consumer contracts, where the consumer is protected as a weaker party to the contract and from detective advertising of the credit offer. 
1. violation of the provisions to resolve proceedings within a reasonable time and,

2. violation of provisions due to arbitrary assessment and nonassessment of derived facts and evidence and due to arbitrary and incorrect application of Article 47, Article 103, Article 105 of the Law on Obligations; Article 561998 LoFC; and that the court did not appreciate, let alone apply the provisions of Article 11, Article 12, Article 13, Article 15, Article 26, Article 41, Article 43, Article 46, paragraph 2, Article 47, Article 50 paragraph 1, Article 100, Article 117-124, Article 121 paragraph 1, Article 142 paragraph 1, Article 394 and 395 paragraphs 1 and 2, Article 1065 and Article 1066 of the LOR; Article 2 and 3 d) and g), Article 52a, Article 93, paragraph 1, Article 94, Article 95, Article 96 d) of the CPL; Article 1, Article 2, Article 32 and 33 of the CBL; Article 3 of the Council Directive 93/13/EEC; Article 5of the LoFC from 2010; Article 3, Chapter VII of Constitution of F BiH; Article $70 / 1$ of the SAA; Article 38 of the EU Charter of Fundamental Rights.

\section{References}

[1] Stjepo Pranjic, State Management: Foundations of New State Management and State Governance, University Press, Sarajevo, 2017. p. 344-398.

[2] Finding and opinion of the Court Expert, no.: 580 P 102778 18 P 2, dated 23 August 2018, p. 8.

[3] Jozo Cizmic, Commentary on the Law on Civil Procedure of the Federation of $\mathrm{BiH}$, Privredna štampa, Sarajevo, 2009, p. 202.

[4] Jim Marrs, The Trillion-Dollar Conspiracy, HarperCollins ebooks, 2010.

[5] Law on Obligatory Relations (LOR), published in the "Official Gazette of the SFRY," no. 29/78, 39/85, 45/89, 57/89, "Official Gazette of RBBH," no. 2/92, 13/93, 13/94, "Official Gazette of the F BiH," no. 29/03, 42/11.

[6] Consumer Protection Law (CPL) in BiH, "Official Gazette of BiH, "no: 25/06 and 88/2015.
[7] Silvija Petric, Legal Problems of Consumer Lending in the Croatian Legal System, Loan Agreement in Swiss FrancProceedings of the International Legal Conference, BL, 11.11.2016.

[8] Judgment of the Municipal Court in Mostar No. $580 \mathrm{P}$ 10277818 P 2, dated 24 December 2018.

[9] Decision of the Supreme Court of FBiH, No.: 580 P 135023 16 Spp, dated 25.05.2016.

[10] Decision of the Mostar County Court, No.: 580 P 10247113 Gž dated 17 March 2014.

[11] Report of a court expert in a legal matter, no.: $580 \mathrm{P} 102778$ $11 \mathrm{P}$, Mostar, 14.05.2014. p. 13 point 15.

[12] Genc Trnavci, Currency Clause in Swiss Francs in BiH: A Classic Case of Usury Leading into Debt Slavery or Fair Banking, Swiss Franc Loan Agreement - Proceedings of the International Legal Conference, Banja Luka, 11 November 2016. p. 93-98; p. 120.

[13] Tamara C., Interpretive effect of European Law in Membership and before EU membership, Collected Papers of Zagreb Law Faculty, Vol. 56, 5/2006, p. 1443.

[14] Stjepo Pranjic, Acts of implementation of currency clause in $\mathrm{CHF}$ and clause of variable interest rate are prohibited competition practices, Transition: Journal of Economics \& Politics of Transition. Jul-Dec 2016, Vol. 18 Issue 37, p. 14-37.

[15] Stjepo Pranjic, Loan Contracts approved in CHF are (not) void, Academy of Sciences and Arts of Bosnia and Herzegovina, Dialogue: Journal for Philosophy and Social Theory. 2014. No. 16. p. 84-113.

[16] Consumer Law Compendium, Comparative Analysis, Edited by Prof. Dr. Hans chulte-Nölke in co-operation with Dr. Christian Twigg-Flesner and Dr. Martin Ebers April 07, C. Unfair Contract Terms Directive (93/13) 341 C. Unfair Contract Terms Directive (93/13), Drafted by Martin Ebers, http://www.euconsumelaw.org/consumerstudy_part2c_en.pdf.

[17] Laxton, Douglas and Eswar Prasad, 2001, Possible Effects of European Monetary Union on Switzerland A Case Study of Policy Dilemmas Caused by Low Inflation and the Nominal Interest Rate Floor, Journal of Policy Modeling, Vol. 23, Issue 5 (July) pp. 531-51. 